\title{
Environmental Occurrence and Ecological Risk of Bisphenol A in Erhai Lake Basin Away From Industrial Regions in China
}

\author{
Jian Shen', Yanming Sui ${ }^{1}$, Jimeng Feng ${ }^{1}$, Xinze Wang ${ }^{1 *}$, Xueying Li², Shiyi Jiang², \\ Zhenyu Zhang ${ }^{2}$, Jianting $\mathrm{Zi}^{2}$, Tianyang $\mathrm{Sun}^{2}$, Ying Gao², Hainan Kong ${ }^{1}$ \\ ${ }^{1}$ School of Environmental Science and Engineering, Shanghai Jiao Tong University, Shanghai, China \\ ${ }^{2}$ Yunnan Dali Research Institute of Shanghai Jiao Tong University, Dali, China
}

Received: 17 April 2020

Accepted: 6 June 2020

\begin{abstract}
The environmental distribution and migration of bisphenol A (BPA) has attracted attention due to its widespread use. The Erhai Lake Basin is dominated by agricultural production and tourism, and almost no industry. In this research, BPA pollution in the non-industrial region was investigated. BPA was found in all samples of inflow rivers, with concentrations ranging $2.80 \mathrm{ng} / \mathrm{L} \sim 61.85 \mathrm{ng} / \mathrm{L}$. The measured 15 rivers that account for $78.7 \%$ of the total inflow volume were inputting BPA concentration of $20.69 \mathrm{ng} / \mathrm{L}$ into Erhai Lake with an annual load of $8.54 \mathrm{~kg} /$ year. The measured BPA removal efficiency of sewage treatment plants ranged $49.8 \% \sim 92.8 \%$. Oxidation Ditch and $\mathrm{A}^{2} \mathrm{O}-\mathrm{MBR}$ treatment process achieved the better BPA removal efficiency. The amount of BPA discharged directly to Erhai Lake from the effluent of the sewage plants each year was $1.63 \mathrm{~kg}$. Based on the above research, a multimedia model of QWASI was established, and water concentration calculated was $0.203 \mathrm{ng} / \mathrm{L}$. A PNEC value considering more sensitive receptors was applied to this study, and it was indicated that there was a certain ecological risk in the water of the Boluo River estuary, while other rivers and lake were relatively safe. It was revealed that the ecological risk of BPA was relatively low in the Erhai Lake.
\end{abstract}

Keywords: BPA, non-industrial regions, occurrence, ecological risk, multimedia model

\section{Introduction}

Bisphenol A, which is also called BPA, has been predominantly used in many consumer products, including plastics (as polymers, polycarbonate plastics), PVC, food packaging, dental sealants, and thermal receipts. As one of the most produced and consumed

*e-mail: xinzewang@sjtu.edu.cn chemicals in the world, BPA has become a public health problem through extensive and continuous exposure $[1,2]$. Many scholars paid attention to the exposure and release of BPA. A related study in Taiwan [3] pointed out that there was almost no risk of BPA intake through diet, and BPA was ingested by the human body mainly due to other exposures. Morgan [4] studied the content of BPA in the urine of 50 American adults and found that the median BPA concentration in human urine was $2.07 \mu \mathrm{g} / \mathrm{L}$. Through their life contact observation, 
the proportion of BPA intake from the diet was about $20 \%$, while contacting other sources seemly dominate. Woerden [5], Karrer [6] and many scholars also obtained similar research conclusions [7]. It has been proved that BPA exists mainly in natural waters, sediments, soil, as well as sewage and wastewater sludge, with a concentration ranging from nanogram to microgram level [8-10], posing a greater threat to humans and animals. After entering human body, BPA can disrupt normal cellular functions by acting as an estrogen agonist and an androgen antagonist [11]. It is suspected that BPA may affect human development throughout the fetal period [12] and may cause cancer. Because of its estrogen activity, it has been shown to reduce sperm count and sperm activity, and to be toxic to the liver, and may even be associated with chronic human diseases such as cardiovascular disease and diabetes.

BPA could migrate and transform in environment through processes, including diffusion, adsorption, and degradation. It is difficult to hydrolyze under natural conditions. The response strategies to control BPA pollution are mainly through various methods to decompose, transform and remove. Currently, the research methods of BPA degradation include physical and chemical methods, microbial degradation, and advanced oxidation [13, 14]. Bertanza's research [9] indicated that using different wastewater treatment process schemes, such as MBR (membrane bioreactor) and CASS (circulating activated sludge system), the BPA removal rate can reach $70 \%$. Hu's study [15] clarified the conversion products of BPA in the ozonation process of sewage plants, aerobic soils and water. Soil is also one of the important media for BPA adsorption and degradation, and BPA has a fast mineralization rate and poor migration in soil [16]. Chen [17] found that sodium alginate/ultrasound assistance could significantly improve the biodegradation rates of BPA in soil.

Based on the characteristics of BPA industrial sources, people usually think that BPA pollution in industrial areas is more serious, while BPA in remote, non-industrial areas, or agricultural economically dominant areas will be lower. In this research, BPA pollution in the non-industrial region was investigated. The study also analyzed the removal efficiency of BPA by major sewage treatment plants. Based on this, a fugacity multimedia model was established to simulate the BPA occurrence status in various environmental media and evaluate environmental risk in the Erhai Lake.

\section{Materials and Methods}

\section{Overview of Study Area}

Erhai Lake is located in Yunnan Province, Southwest of China, and it is an important source of drinking water in Dali Prefecture, Yunnan Province. The basin has a total area of $2565 \mathrm{~km}^{2}$, including lake area of $252.1 \mathrm{~km}^{2}$. Erhai Lake has a maximum water depth of $21.3 \mathrm{~m}$, an average water depth of $10.8 \mathrm{~m}$, and a lake capacity of 2.959 billion $\mathrm{m}^{3}$. Erhai Lake is a typical plateau lake with a small annual runoff. The lake
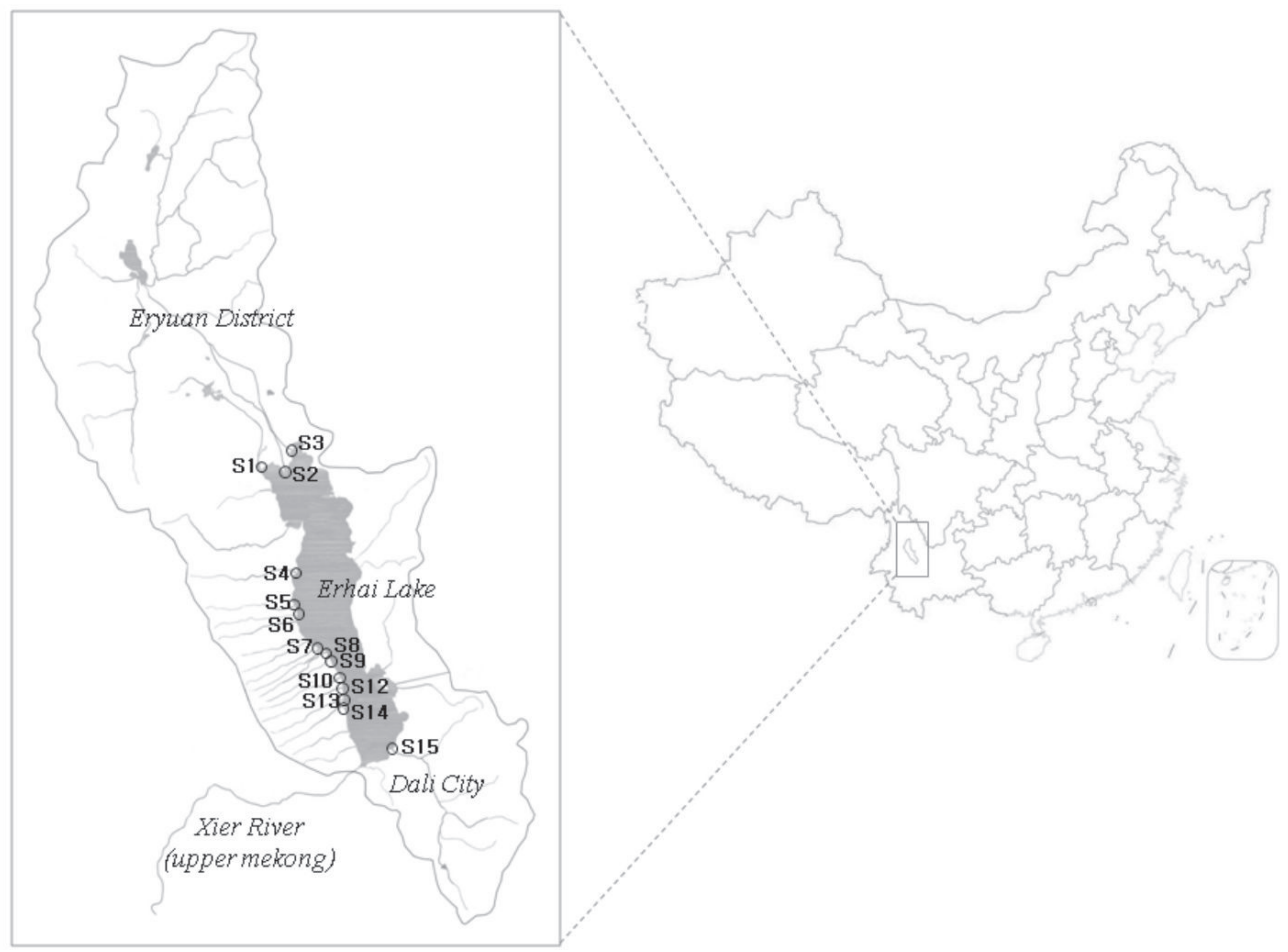

Fig. 1. Study area location and sampling sections. 
water exchange cycle takes several years. Due to its remote location, the Erhai Lake Basin is dominated by agricultural production and tourism, and there is almost no industry. Therefore, the water quality of Erhai Lake has been excellent so far.

\section{Site Selection}

Erhai Lake has 117 inflow rivers with yearly average inflow of 825 million $\mathrm{m}^{3}$, and only one outflow river, which is called Xier River (upper Mekong River). The three rivers with the largest inflow are located in the north of Erhai Lake, namely Luoshi River, Yongan River and Miju River, contributing 50\% of total inflow volume. Other large inflow rivers also include the Boluo River in the south and 18 streams in the west. This study selected the 15 largest rivers flowing into Erhai Lake, setting up sampling sections for BPA detection at the estuary. The sampling sections location are shown in Fig. 1. In addition, in order to investigate the BPA removal efficiency of sewage treatment plants in Erhai Basin. The inlet and outlet water of the main sewage treatment plants were sampled to detect the BPA concentration. Information of sampling sections as Table 1. In the preliminary work, we regularly monitored the flow volume of selected 15 rivers into the lake, and the data are also listed in Table 1. Two samples were taken at each sampling section.

Table 1. Information of sampling sections.

\begin{tabular}{|c|c|c|c|}
\hline Sampling number & Name of infow river & Latitude and longitude of estuary & Annual inflow volume $-2019\left(\times 10^{4} \mathrm{~m}^{3}\right)$ \\
\hline S1 & Luoshi River & $25.943508^{\circ} \mathrm{N}, 100.098616^{\circ} \mathrm{E}$ & 6609.807 \\
\hline S2 & Miju River & $25.926798^{\circ} \mathrm{N}, 100.133399^{\circ} \mathrm{E}$ & 9017.867 \\
\hline S3 & Yongan River & $25.954445^{\circ} \mathrm{N}, 100.141001^{\circ} \mathrm{E}$ & 5615.688 \\
\hline S4 & Wanhua River & $25.868505^{\circ} \mathrm{N}, 100.140747^{\circ} \mathrm{E}$ & 683.209 \\
\hline S5 & Yang River & $25.819498^{\circ} \mathrm{N}, 100.143812^{\circ} \mathrm{E}$ & 2483.872 \\
\hline S6 & Mangyong River & $25.799785^{\circ} \mathrm{N}, 100.143074^{\circ} \mathrm{E}$ & 3478.54 \\
\hline S7 & Jin River & $25.770484^{\circ} \mathrm{N}, 100.148407^{\circ} \mathrm{E}$ & 694.553 \\
\hline S8 & Mei River & $25.736493^{\circ} \mathrm{N}, 100.174900^{\circ} \mathrm{E}$ & 88.757 \\
\hline S9 & Tao River & $25.733980^{\circ} \mathrm{N}, 100.178460^{\circ} \mathrm{E}$ & 216.5 \\
\hline S10 & Zhonghe River & $25.718848^{\circ} \mathrm{N}, 100.187559^{\circ} \mathrm{E}$ & 122.931 \\
\hline S11 & Baihe River & $25.699636^{\circ} \mathrm{N}, 100.204390^{\circ} \mathrm{E}$ & 267.355 \\
\hline S12 & Long River & $25.686205^{\circ} \mathrm{N}, 100.205739^{\circ} \mathrm{E}$ & 654.061 \\
\hline S13 & Qingbi River & $25.678176^{\circ} \mathrm{N}, 100.209512^{\circ} \mathrm{E}$ & 359.232 \\
\hline S14 & Mocan River & $25.673353^{\circ} \mathrm{N}, 100.207481^{\circ} \mathrm{E}$ & 442.71 \\
\hline S15 & Boluo River & $25.614500^{\circ} \mathrm{N}, 100.281889^{\circ} \mathrm{E}$ & 1739.246 \\
\hline \multicolumn{3}{|c|}{ Sum of annual flow above } & 32474.328 \\
\hline \multicolumn{3}{|c|}{ All inflow to the lake in 2019} & 41257.69 \\
\hline Sampling number & $\begin{array}{c}\text { Major sewage treatment } \\
\text { plants }\end{array}$ & latitude and longitude of plants & Inlet or outlet \\
\hline D1i & \multirow{2}{*}{ Dayutian } & \multirow{2}{*}{$25.574493^{\circ} \mathrm{N}, 100.199249^{\circ} \mathrm{E}$} & Inlet \\
\hline D1o & & & Oulet \\
\hline $\mathrm{D} 2 \mathrm{i}$ & \multirow{2}{*}{ Haidong } & \multirow{2}{*}{$25.699396^{\circ} \mathrm{N}, 100.274867^{\circ} \mathrm{E}$} & Inlet \\
\hline $\mathrm{D} 2 \mathrm{o}$ & & & Oulet \\
\hline D3i & \multirow{2}{*}{ Shuanglang } & \multirow{2}{*}{$25.922345^{\circ} \mathrm{N}, 100.192492^{\circ} \mathrm{E}$} & Inlet \\
\hline D3o & & & Oulet \\
\hline D4i & \multirow{2}{*}{ Shangguan } & \multirow{2}{*}{$25.955189^{\circ} \mathrm{N}, 100.130676^{\circ} \mathrm{E}$} & Inlet \\
\hline $\mathrm{D} 4 \mathrm{o}$ & & & Oulet \\
\hline D5i & \multirow{2}{*}{ Zhoucheng } & \multirow{2}{*}{$25.901317^{\circ} \mathrm{N}, 100.109351^{\circ} \mathrm{E}$} & Inlet \\
\hline D5o & & & Oulet \\
\hline
\end{tabular}




\section{Sampling Procedure}

Samples collection of surface water was under the water surface $5 \mathrm{~cm}$ in order to prevent floating objects, suspended oil and other impurities on the water surface from mixing into the sampler. Water samples of urban sewage treatment plants were taken from the sewage inlet and the total discharge port of the sewage treatment facility. The glass container required for sampling should be cleaned in advance. The sampling position, sampling time and sampling temperature were recorded curing material collection. The water samples taken by the sampler were transferred to a brown glass bottle with a capacity of $1 \mathrm{~L}$ filled completely, sealed and taken back to the laboratory to be refrigerated in a $4^{\circ} \mathrm{C}$ refrigerator. Considering that other microbial reactions could cause analysis errors, water samples were fixed with $1 \mathrm{~g} / \mathrm{L}$ ascorbic acid. In order to ensure the accuracy of the analysis results, the samples were processed by solid phase extraction within one week and sent to the GC-MS for testing within two weeks.

\section{SPE Extraction and Derivatization}

Before extraction of the sample, the solid-phase extraction cartridge was rinsed with a suitable solvent, so that the analyte could be in close contact with the surface of the solid phase, thereby improving the recovery rate and reproducibility. In this experiment, $2 \times 3 \mathrm{~mL}$ of $\mathrm{n}$-hexane, $2 \times 3 \mathrm{~mL}$ of ethyl acetate, $2 \times 3 \mathrm{~mL}$ of methanol, and $2 \times 5 \mathrm{~mL}$ of ultrapure water were used to activate the column. The dripping speed of the liquid was about $1 \mathrm{~mL} / \mathrm{min}$ and time 5 minutes to make sure that the filler was thoroughly soaked in the activating reagent. $0.5 \sim 1.0 \mathrm{~L}$ of pre-treated water sample was imported into the activated SPE cartridges under a certain vacuum pressure, while flow rate was controlled at about $4 \mathrm{~mL} / \mathrm{min}$, then the BPA and some impurities were adsorbed and retained on the SPE cartridges. The cartridges were washed by $10 \mathrm{~mL}$ of $10 \%$ methanol in water with flow rate of approximately $5 \mathrm{~mL} / \mathrm{min}$. The cartridges were eluted with $10 \mathrm{~mL}$ of ethyl acetate, while the drip rate was controlled at about $1 \mathrm{~mL} / \mathrm{min}$, and the eluate was collected. Dried BPA eluent under mild high-purity nitrogen at $30^{\circ} \mathrm{C}$ was added $25 \mu \mathrm{L}$ of BSTFA (containing $1 \%$ by mass TMCS) reagent and 50 $\mu \mathrm{L}$ of pyridine solution, derivatized with microwave $300 \mathrm{w}$ for 4 minutes. After nitrogen blowing, $400 \mu \mathrm{L}$ of $1 \mathrm{mg} / \mathrm{L}$ internal standard Mirex was added to dissolve BPA, and then transferred to a $2 \mathrm{ml}$ sample bottle for detection.

\section{Analysis by GC-MS}

The testing instrument was Thermo Fisher TRACE 1300-ISQ Series Quadrupole. GC conditions: TR-5MS quartz capillary column $(30 \mathrm{~m} \times 0.25 \mathrm{~mm} \times 0.25 \mu \mathrm{m})$; high-purity helium (99.999\%) carrier gas, constant current mode $(1.2 \mathrm{~mL} / \mathrm{min}$ carrier gas flow rate); splitless injection, each sampling volume was $1.0 \mu \mathrm{L}$, with the inlet temperature of $280^{\circ} \mathrm{C}$; septum purge $5.0 \mathrm{~mL} / \mathrm{min}$; column heating program: initial temperature $50^{\circ} \mathrm{C}$, hold for $2 \mathrm{~min}$; rise to $260^{\circ} \mathrm{C}$ at the rate of $20^{\circ} \mathrm{C} / \mathrm{min}$, hold for $5 \mathrm{~min}$; then increase to $280^{\circ} \mathrm{C}$ at the rate of $10^{\circ} \mathrm{C} / \mathrm{min}$, holding for 5 minutes. MS condition: Electron bombardment ion source (EI), ionization voltage $70 \mathrm{eV}$; ion source temperature $250^{\circ} \mathrm{C}$, transmission line temperature $280^{\circ} \mathrm{C}$; solvent delay time 10min; full scan mode (SCAN) for qualitative and selective ion scan mode (SIM) for quantification. The analysis was performed using Xcalibur software to determine BPA and internal standard.

In order to examine the accuracy and precision of the method, a standard solution containing 50ng and $500 \mathrm{ng}$ of the test component was used as a sample, and the measurement was performed 7 times within one day. The average spike recovery of BPA was $98.0 \%$. The relative standard deviation (RSD) was $0.4 \% \sim 6.8 \%$. Limits of quantification were defined as 10 times the noise level of the baseline in the chromatograms. For data analysis, all data of result shown through in figures are expressed as mean \pm standard deviation.

\section{Multimedia Model Calculation}

Currently, widely used multi-media model is the fugacity model proposed by Professor Donald Mackay of the Environmental Model Research Center of the University of Trent, Canada. This method is based on the fugacity concept and uses the principle of mass balance. Researchers have proposed a number of different multimedia fugacity models. These models have been softwareized and provided to users for related scientific research, including SimpleBox, QWASI, CalTOX, ChemCAN, EQC, TaPL3, etc., while each of these models are not very different, slightly different according to various objects. For example, QWASI is a simplified lake model. The purpose is to analyze and calculate the chemical exchange of chemicals in water, air and water-sediment and the chemical transformation in a single phase, so it is not suitable for chemical behavior analysis of land and rivers; EQC sets up a fixed multimedia environment system, which cannot be directly used for regional environment simulation; SimpleBox, CalTOX, ChemCAN, and TaPL3 can be applied to chemicals in regions On the distribution and risk assessment of environmental media, the reliability of the models have been verified [18-27].The fugacity model also has obvious shortcomings, because the existing fugacity models assume that the spatial characteristics of each medium are uniform, that is, the fugacity of each point in each medium is equal. If the model is used for heterogeneous phases, the behavior characteristics of pollutants cannot be reflected spatial variability, the accuracy of the model would be reduced. Taking the Erhai Lake Basin as an example. Erhai Lake is a typical plateau lake, showing a small annual runoff. Dozens of rivers flow into the lake but only 
one river out. Therefore, lake's water body stays for several years, and the detention time of inflow rivers sub-basin is short but the detention time in the lake is very long. Based on the environmental characteristics of the Erhai Lake Basin, in order to use the multimedia model to study the environmental behavior of BPA, in this study, monitoring of rivers and sewage plants were implemented. After all, human production and living behaviors occur on land and near rivers. For the Erhai Lake Basin, there is another important factor. At present, local governments have built a pollution interception system around the lake. Except for rivers and effluent of sewage plants that mainly flow into the lake, there are basically no cases where pollutants directly enter the lake.

In this study, the QWASI model (version 3.10) was employed, which is a Mackay-type multimedia fate model describing the fate of a chemical in a given lake. The QWASI model is suitable for water bodies with uniformly mixed water and particle streams. When the system is in a steady state, that is, the lake is exposed to constant input conditions for a long time, the sum of all input rates is equal to the sum of all output rates. Based on the diversification of BPA exposure pathways, it is difficult to estimate the production and emissions of BPA and downstream products within the Erhai Lake Basin. In this study, the pathway of BPA release into the environment is assumed to be through sewage discharge. The amount of emissions was calculated based on the removal efficiency of sewage treatment plants, which was tested in this study. BPA concentration data input into Erhai Lake based on experimentally measured river data. Experimentally measured data were used as BPA concentration of advection into Erhai Lake in the QWASI.

The required data was input to apply the QWASI model. The physicochemical properties of BPA and the geographical parameters for Erhai Lake are summarized in Table 2.

\section{Results and Discussion}

\section{Distribution of BPA in Inflow Rivers of Erhai Lake}

Fig. 2 shows distribution of BPA in inflow rivers of Erhai Lake. BPA was found in all samples, with concentrations ranging from $2.80 \mathrm{ng} / \mathrm{L}$ to $61.85 \mathrm{ng} / \mathrm{L}$. Concentration levels were similar to the studies by Moreira [28], Arditsoglou [29], Funakoshi [30], Fu [31], Kuch [32] and Loos [33], showing BPA occurrence of rivers and estuaries in these locations including Netherlands, Brazil, Qingdao of China, Japan, Germany and Belgium. In the Erhai Lake Basin, the concentration of the three rivers (Luoshi River, Miju River and Yongan River) with the largest inflow to the lake was between $13.4 \mathrm{ng} / \mathrm{L}$ and $24.6 \mathrm{ng} / \mathrm{L}$, which represented the main pollutant transport channel of the river into the lake. The river with the highest concentration was the Boluo River. Boluo River subbasin was where the Dali Economic Development Zone was located. The vast majority of industrial enterprises in the Erhai Lake Basin were located here, including tractor manufacturers, organic fertilizer production plants, livestock and poultry farms, transportation and logistics bases, and automobile inspection and trading markets. Industry, commerce, and a large number of production and living activities might contribute a lot of BPA emission. However, compared with the BPA river water concentration of $5.03 \mu \mathrm{g} / \mathrm{L} \sim 12 \mu \mathrm{g} / \mathrm{L}$ in some areas of Portugal or the United States [34], the BPA pollution in the inflow rivers of Erhai Lake Basin was much less important.

\section{BPA Removal Efficiency by Sewage Treatment Plants}

Dayutian Sewage Plant is the most important sewage treatment plant in Dali City, with treatment capacity of

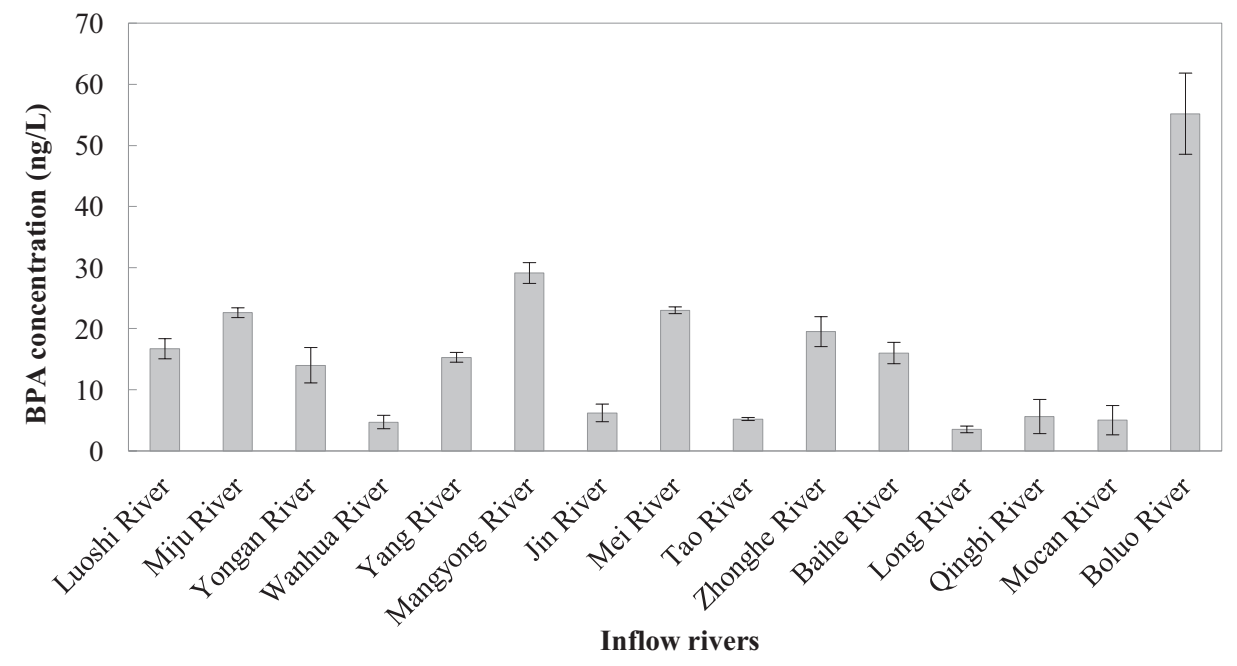

Fig. 2. Distribution of BPA in inflow rivers of Erhai Lake. 
Table 2. Geographic parameters and chemical parameters.

\begin{tabular}{|c|c|c|}
\hline Parameter & Unit & Parameter value \\
\hline \multicolumn{3}{|c|}{ BPA } \\
\hline Molar mass & $\mathrm{g} / \mathrm{mol}$ & 228 \\
\hline Temperature & ${ }^{\circ} \mathrm{C}$ & 25 \\
\hline Vapour pressure & $\mathrm{Pa}$ & $4.0 \mathrm{E}-06$ \\
\hline Water solubility & $\mathrm{g} / \mathrm{m}^{3}$ & 300 \\
\hline LogKow & l & 2.76 \\
\hline Melting point & ${ }^{\circ} \mathrm{C}$ & 159 \\
\hline Degradation half-life in water ${ }^{a}$ & $\mathrm{~h}$ & 363.2 \\
\hline Degradation half-life in sediment ${ }^{a}$ & $\mathrm{~h}$ & 3007.8 \\
\hline \multicolumn{3}{|c|}{ Lake properties } \\
\hline Water surface area & $\mathrm{m}^{2}$ & $252.1 \mathrm{E}+06$ \\
\hline Water volume & $\mathrm{m}^{3}$ & $29.59 \mathrm{E}+08$ \\
\hline Sediment active layer depth & $\mathrm{m}$ & 0.5 \\
\hline Concentration of solids in water column & $\mathrm{mg} / \mathrm{L}$ & 2 \\
\hline Concentration of solids in inflow water & $\mathrm{mg} / \mathrm{L}$ & 5 \\
\hline Concentration of solids in sediment & $\mathrm{m}^{3} / \mathrm{m}^{3}$ & 0.3 \\
\hline Density of solids in water & $\mathrm{kg} / \mathrm{m}^{3}$ & 2400 \\
\hline Density of solids in sediment & $\mathrm{kg} / \mathrm{m}^{3}$ & 2400 \\
\hline Density of solids in aerosols & $\mathrm{kg} / \mathrm{m}^{3}$ & 1500 \\
\hline Organic carbon fraction of solids in water column & $\mathrm{g} / \mathrm{g}$ & 0.2 \\
\hline Organic carbon fraction of solids in sediment & $\mathrm{g} / \mathrm{g}$ & 0.04 \\
\hline Organic carbon fraction of solids in inflow water & $\mathrm{g} / \mathrm{g}$ & 0.2 \\
\hline Organic carbon fraction of solids in resuspended sediment & $\mathrm{g} / \mathrm{g}$ & 0.04 \\
\hline \multicolumn{3}{|c|}{ Flows and transfer coefficients } \\
\hline River water inflow ${ }^{\mathrm{b}}$ & $\mathrm{m}^{3} / \mathrm{h}$ & 47097.82 \\
\hline Water outflow rate ${ }^{b}$ & $\mathrm{~m}^{3} / \mathrm{h}$ & 55365.3 \\
\hline Deposition rate of solids & $\mathrm{g} /\left(\mathrm{m}^{3} \cdot \mathrm{d}\right)$ & 1.4 \\
\hline Burial rate of solids & $\mathrm{g} /\left(\mathrm{m}^{3} \cdot \mathrm{d}\right)$ & 0.5 \\
\hline Resuspended rate of solids & $\mathrm{g} /\left(\mathrm{m}^{3} \cdot \mathrm{d}\right)$ & 0.5 \\
\hline Aerosol dry deposition velocity & $\mathrm{m} / \mathrm{h}$ & 10.8 \\
\hline Scavenging ratio & vol air per vol rain & $2.0 \mathrm{E}+05$ \\
\hline Rain rate & $\mathrm{m} /$ year & 0.82 \\
\hline Air side mass transfer coefficients of volatization & $\mathrm{m} / \mathrm{h}$ & 3 \\
\hline Water side transfer coefficients of volatization & $\mathrm{m} / \mathrm{h}$ & 0.03 \\
\hline Mass transfer coefficients of sediment-water diffusion & $\mathrm{m} / \mathrm{h}$ & $1.0 \mathrm{E}-04$ \\
\hline \multicolumn{3}{|c|}{ Emissions and inflows } \\
\hline Direct discharges into water ${ }^{c}$ & $\mathrm{~kg} /$ year & 1.63 \\
\hline Chemical concentration in inflow water $^{c}$ & $\mathrm{ng} / \mathrm{L}$ & 20.69 \\
\hline
\end{tabular}

a: Reference to chemical database of the SimpleBox 4.0 model (developed by the Dutch Institute of Public Health and the Environment). b: Data collected in this study. c: Data through measured and calculated at each of the studied rivers and plants. 
$129,000 \mathrm{~m}^{3} / \mathrm{d}$, and it has accepted the main domestic sewage in Dali City. The other sewage treatment plants mainly treat township domestic sewage, with the treatment capacity of $5,000 \mathrm{~m}^{3} / \mathrm{d}$ (Haidong Plant), 2,000 $\mathrm{m}^{3} / \mathrm{d}$ (Shuanglang Plant), 2,000 $\mathrm{m}^{3} / \mathrm{d}$ (Shangguan Plant) and 2,000 $\mathrm{m}^{3} / \mathrm{d}$ (Zhoucheng Plant). By measuring the BPA inlet and outlet of the sewage plants (shown in Fig. 3), we found that the sewage treatment plants of Erhai Lake Basin had insufficient treatment efficiency for BPA. The measured BPA removal efficiency ranged from 49.8\% 92.8\%. The sewage treatment plant with the highest treatment efficiency was Zhoucheng Plant, which also had the highest intake BPA concentration of $563.7 \mathrm{ng} / \mathrm{L}$. The high inlet concentration might be due to the distribution of some ethnic dyeing factories near Zhoucheng. Data of Dayutian Sewage Plant could reflect the BPA release concentration (302.3 ng/L) of Dali urban residents. Woerden's research [5] indicated that average BPA concentration of human urinary was $2.3 \mu \mathrm{g} / \mathrm{L}$. Considering the dilution effect of other types of sewage, the measured concentration levels were reasonable in the absence of industrial emissions. In addition, the treatment process of sewage plants also had a significant impact on BPA removal efficiency. $\mathrm{A}^{2} \mathrm{O}-\mathrm{MBR}$ process was used in Dayutian Plant, and Orbel Oxidation Ditch in Zhoucheng Plant. Due to lower cost, other township sewage treatment plants (Haidong Shuanglang and Shangguan) applied diatomite flocculation sedimentation process. Viewing from BPA removal efficiency, Oxidation Ditch $>\mathrm{A}^{2} \mathrm{O}-\mathrm{MBR}>$ Flocculation.

\section{Occurrence and Ecological Risk of BPA in Erhai Basin}

Assuming that the BPA advection from the air into the Erhai Lake was ignored, the measured BPA concentration and flow volume data of all inflow rivers were applied to calculate the concentration of BPA input through advection of river water, calculating as follows.

$$
\mathrm{C}_{\mathrm{BPA}}=\sum_{\mathrm{i}}^{\mathrm{n}}\left(\mathrm{C}_{\mathrm{i}} \times \mathrm{AF}_{\mathrm{i}}\right) / \sum_{\mathrm{i}}^{\mathrm{n}} \mathrm{AF}_{\mathrm{i}}
$$

$\boldsymbol{C}_{\boldsymbol{B P A}}$ : average BPA concentration in inflow rivers; $\boldsymbol{n}$ : number of BPA measured inflow rivers; $\boldsymbol{i}$ : a measured inflow river; $C_{i}$ : BPA concentration in a inflow river; $\boldsymbol{A F}_{\boldsymbol{i}}$ : annual flow volume of a measured inflow river.

Based on the excellent pollution interception system of Erhai Lake, it was assumed that the BPA discharge channel was through only sewage treatment plants outlet. Mass of BPA emissions to Erhai Lake was calculated as follows.

$$
E_{B P A}=\sum_{j}^{m} C_{j} \times V_{j} \times N
$$

$\boldsymbol{E}_{\boldsymbol{B P A}}$ : Mass of BPA directly discharged to Erhai Lake per year; $\boldsymbol{m}$ : number of sewage treatment plants; $\boldsymbol{j}$ : a measured sewage treatment plant; $\boldsymbol{C}_{j}$ : BPA concentration in effluent of a sewage treatment plant; $\boldsymbol{V}_{j}$ : treated water volume of a sewage treatment plant per day; $N$ : days per year, value was 365 .

Through the established QWASI model and related input parameters, occurrence and fate of BPA in Erhai Lake was simulated. The predicted environmental concentrations in the four bulk environmental compartments of air, water and sediment were calculated. Mass balances and diagram of QWASI model output results are shown in Table 3 and Fig 4. It can be clearly seen that bulk water account for $96.71 \%$ of total mass in the system. Water and sediment concentrations calculated in QWASI were $0.203 \mathrm{ng} / \mathrm{L}$ and 2.04E-04 ng/g, respectively. The output showed

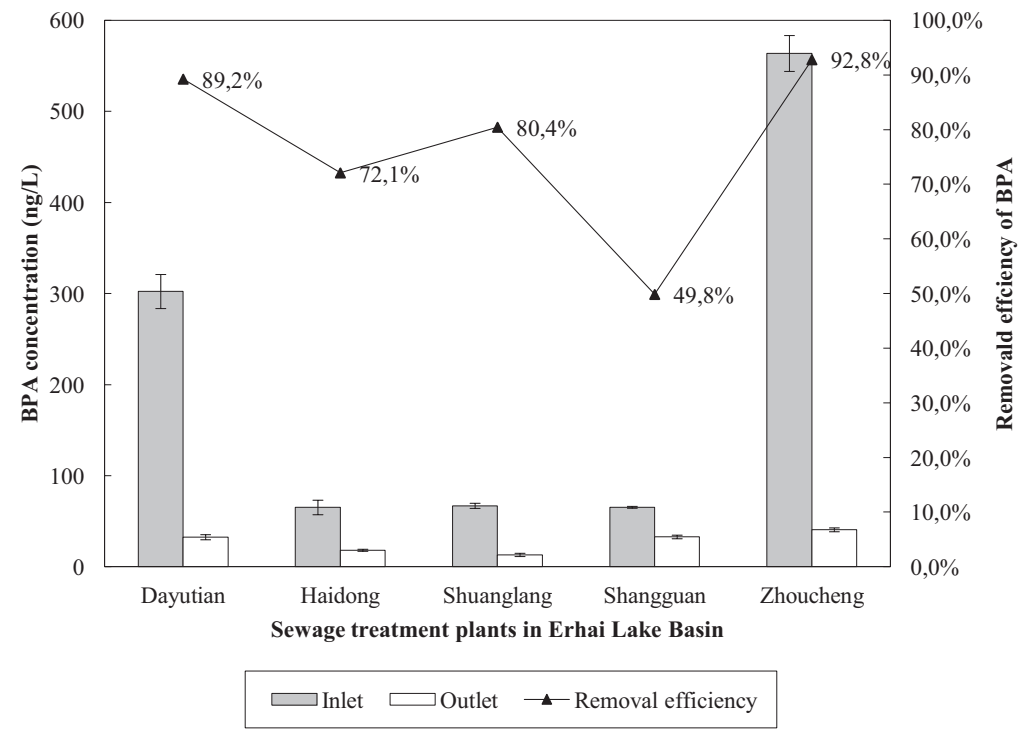

Fig. 3. BPA removal efficiency sewage treatment plants of Erhai Lake Basin. 
Table 3. Mass balances in QWASI simulation.

\begin{tabular}{|c|c|c|}
\hline In the System & Unit $(\mathrm{mol} / \mathrm{h})$ & Unit $(\mathrm{kg} /$ year $)$ \\
\hline Total chemical inputs & $5.09 \mathrm{E}-03$ & 10.17 \\
\hline Emission & $8.16 \mathrm{E}-04$ & 1.63 \\
\hline Inflow & $4.27 \mathrm{E}-03$ & 8.54 \\
\hline Total chemical losses & $5.09 \mathrm{E}-03$ & 10.17 \\
\hline Outflow & $4.92 \mathrm{E}-05$ & 0.0983 \\
\hline Water to air transfer & $8.25 \mathrm{E}-10$ & $1.65 \mathrm{E}-06$ \\
\hline Total transformation & $5.04 \mathrm{E}-03$ & 10.07 \\
\hline Sediment burial & $4.70 \mathrm{E}-09$ & $9.38 \mathrm{E}-06$ \\
\hline
\end{tabular}

that BPA pollution in Erhai Lake was at a relatively low level.

Chronic predicted no effect concentrations (PNECs) for aquatic systems are used to support the assessment of potential risks to aquatic organisms in receiving waters. PNECs for a compound are considered protective of populations, communities, and ecosystems. Traditionally, PNECs are derived by taking the lowest no-observed effect concentration (NOEC) from a set of toxicity studies and dividing by an assessment factor [35]. Species Sensitivity Distribution (SSD methods) was applied by Staples and a PNEC value of $1.6 \mu \mathrm{g} / \mathrm{L}$ were derived. Adamakis [36] investigated the effects of environmentally relevant BPA concentrations $(0.03 \sim 3 \mu \mathrm{g} / \mathrm{L})$ on leaf elongation and cytoskeleton in the seagrass Cymodocea nodosa. They found that the highest BPA concentration $(3 \mu \mathrm{g} / \mathrm{L})$ significantly affected leaf elongation at the beginning of the experiment, and cytoskeleton disturbance was observed even at lower concentrations (around $0.03 \mu \mathrm{g} / \mathrm{L}$ ). Wright-Walters [37] thought that a BPA PNEC of $0.06 \mu \mathrm{g} / \mathrm{L}$ was more appropriate. Because aquatic receptors were more sensitive to BPA, their exposure was greater than previously found. This was due to the fact that Wright-Walters' study had higher sensitivity taxa, such as algae, cyanobacteria, and insects. In ecological assessment, it was assumed that the sensitivity of the ecosystem (PNEC) depended on the most sensitive species. With this PNEC, ecosystems including insects, molluscs, and crustaceans could be protected from the adverse effects of exposure to BPA.

Combining the PNEC value with the data in our study, we found that there was a certain ecological risk in the water of the Boluo River estuary, other rivers were relatively safe, and the effluent concentration of the sewage plant was lower than the PNEC value, which was worth to be pleased with. However, in recent years, with the increase of China's polycarbonate production capacity and output, and the steady growth of the epoxy resin market, China's BPA demand has generally shown a relatively stable growth trend. In 2018, China's apparent consumption of BPA reached 16.675 million tons. Due to wide variety of products and applications, a total production capacity of BPA exceeded 3.8 million tons [38], and apparent consumption of BPA is becoming more and more in China, which is an important BPA producer (Fig. 5). Based on the diversity of BPA products and exposure routes, we should continue to pay attention to the environmental distribution of BPA.

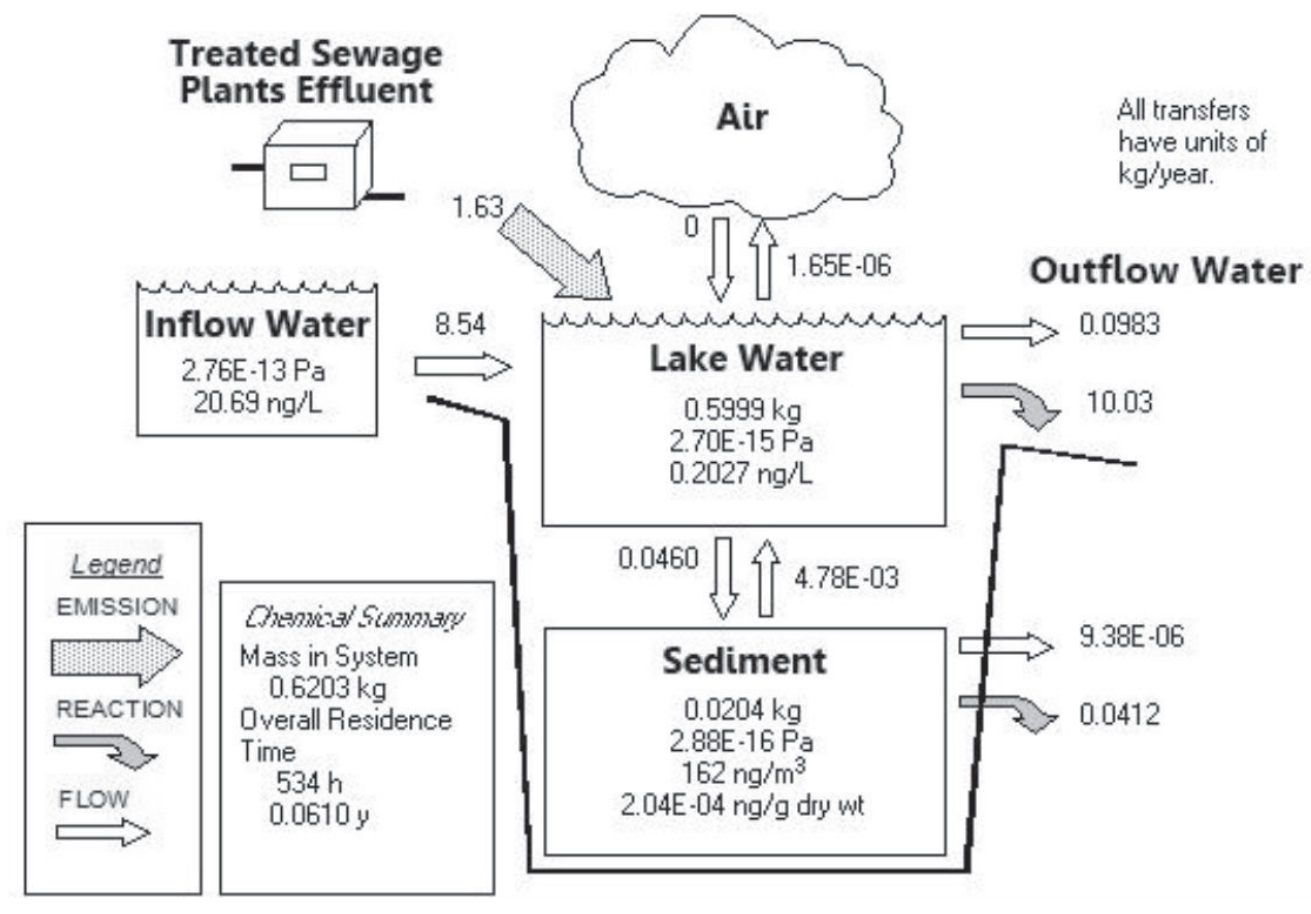

Fig. 4. Fate of BPA in Erhai Lake. 


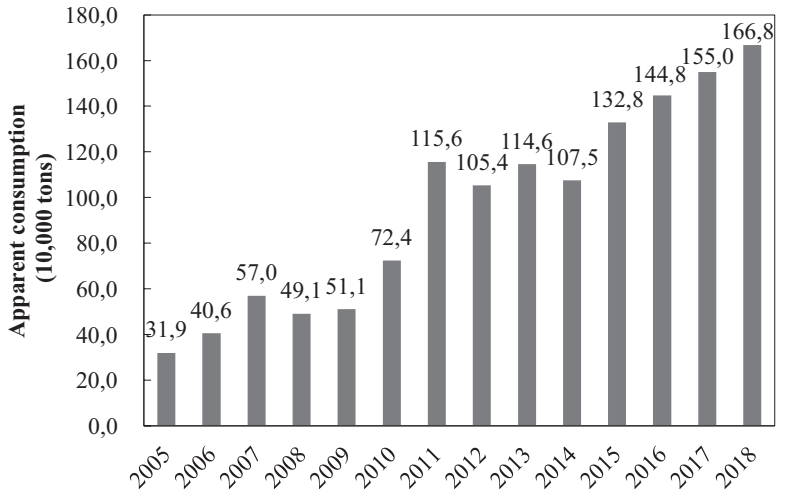

Fig. 5. China's apparent consumption of BPA.

\section{Conclusions}

Erhai Lake is a typical plateau lake in China. The focus on BPA prompted us to conduct this study due to the long residence time of chemicals in the lake.

The results of this research explained that BPA was found in all samples of inflow rivers, with concentrations ranging from $2.80 \mathrm{ng} / \mathrm{L}$ to $61.85 \mathrm{ng} / \mathrm{L}$. The measured 15 rivers that account for $78.7 \%$ of the total inflow volume were inputting BPA concentration of $20.69 \mathrm{ng} / \mathrm{L}$ into Erhai Lake with an annual load of $8.54 \mathrm{~kg} /$ year.

By measuring the BPA inlet and outlet of the sewage plants, we found that the sewage treatment plants of Erhai Lake Basin had insufficient treatment efficiency for BPA. The measured BPA removal efficiency ranged $49.8 \% \sim 92.8 \%$. Oxidation Ditch and $\mathrm{A}^{2} \mathrm{O}-\mathrm{MBR}$ treatment process achieved the better BPA removal efficiency. The amount of BPA discharged directly to Erhai Lake from the effluent of the sewage plants was $1.63 \mathrm{~kg} /$ year.

Through the established QWASI model and related input parameters, occurrence and fate of BPA in Erhai Lake was simulated. Water concentration calculated was $0.203 \mathrm{ng} / \mathrm{L}$, showing that BPA pollution in Erhai Lake was at a relatively low level. A PNEC value considering more sensitive receptors was applied to this study, and it was indicated that there was a certain ecological risk in the water of the Boluo River estuary, while other rivers and lake were relatively safe. It was revealed that the ecological risk of BPA was relatively low in the Erhai Lake Basin, which is far from the heavy and chemical industrial areas. Based on the diversity of BPA products and exposure routes, the environmental distribution and the ecological risk of BPA should be paid more attention to.

\section{Acknowledgements}

QWASI software was provided via the website of the Canadian Environmental Modelling Centre, Trent University. Thanks for their excellent contributions on multimedia modelling.

\section{Conflict of Interest}

The Authors declare no conflict of interest.

\section{References}

1. HUANG R., LIU Z., YIN H., DANG Z., WU P., ZHU N., LIN Z. Bisphenol A concentrations in human urine, human intakes across six continents, and annual trends of average intakes in adult and child populations worldwide: A thorough literature review. Science of The Total Environment. 626, 971, 2018.

2. ROCHESTER J. R. Bisphenol A and human health: A review of the literature. Reproductive Toxicology. 42, 132, 2013.

3. CHEN W.Y., SHEN Y.P., CHEN S.C. Assessing bisphenol A (BPA) exposure risk from long-term dietary intakes in Taiwan. Science of the Total Environment. 543, 140, 2016.

4. MORGAN M.K., NASH M., BARR D.B., STARR J.M., SCOTT CLIFTON M., SOBUS J.R. Distribution, variability, and predictors of urinary bisphenol A levels in 50 North Carolina adults over a six-week monitoring period. Environment International. 112, 85, 2018.

5. VAN WOERDEN I., BRUENING M., MONTRESORLÓPEZ J., PAYNE-STURGES D.C. Trends and disparities in urinary BPA concentrations among U.S. emerging adults. Environmental Research. 176, 2019.

6. KARRER C., ANDREASSEN M., VON GOETZ N., SONNET F., SAKHI A. K., HUNGERBÜHLER K., DIRVEN H., HUSØY T. The EuroMix human biomonitoring study: Source-to-dose modeling of cumulative and aggregate exposure for the bisphenols BPA, BPS, and BPF and comparison with measured urinary levels. Environment International. 136, 105397, 2020.

7. VOM SAAL F.S., WELSHONS W.V. Evidence that bisphenol A (BPA) can be accurately measured without contamination in human serum and urine, and that BPA causes numerous hazards from multiple routes of exposure. Molecular and Cellular Endocrinology. 398 (1-2), 101, 2014.

8. BARNABÉ S., BRAR S.K., TYAGI R.D., BEAUCHESNE I., SURAMPALLI R.Y. Pre-treatment and bioconversion of wastewater sludge to value-added products-Fate of endocrine disrupting compounds. Science of the Total Environment. 407 (5), 1471, 2009.

9. BERTANZA G., PEDRAZZANI R., DAL GRANDE M., PAPA M., ZAMBARDA V., MONTANI C., STEIMBERG N., MAZZOLENI G., DI LORENZO D. Effect of biological and chemical oxidation on the removal of estrogenic compounds (NP and BPA) from wastewater: An integrated assessment procedure. Water Research. 45 (8), 2473, 2011.

10. GRAZIANI N.S., CARRERAS H., WANNAZ E. Atmospheric levels of BPA associated with particulate matter in an urban environment. Heliyon. 5 (4), e01419, 2019.

11. WOZNIAK A.L., BULAYEVA N.N., WATSON C.S. Xenoestrogens at picomolar to nanomolar concentrations trigger membrane estrogen receptor- $\alpha$-mediated $\mathrm{Ca}^{2+}$ fluxes and prolactin release in GH3/B6 pituitary tumor cells. Environmental Health Perspectives. 113 (4), 431, 2005. 
12. RUBIN B.S., SOTO A. M. Bisphenol A: Perinatal exposure and body weight. Molecular and Cellular Endocrinology. 304 (1-2), 55, 2009.

13. CHOI Y.J., LEE L.S. Aerobic Soil Biodegradation of Bisphenol (BPA) Alternatives Bisphenol S and Bisphenol AF Compared to BPA. Environmental Science and Technology. 51 (23), 13698, 2017.

14. ZHOU N., LIU Y., CAO S., GUO R., MA Y., CHEN J. Biodegradation of bisphenol compounds in the surface water of Taihu Lake and the effect of humic acids. Science of the Total Environment. 723, 138164, 2020.

15. HU Y., ZHU Q., YAN X., LIAO C., JIANG G. Occurrence, fate and risk assessment of BPA and its substituents in wastewater treatment plant: A review. Environmental Research. 178, 108732, 2019.

16. SHEN J., WANG X.Z., ZHANG Z., SUI Y.M., WU H.L., FENG J.M., TONG X.N., ZHANG Z.Y. Adsorption and degradation of 14C-bisphenol A in a soil trench. Science of the Total Environment. 607-608, 676, 2017.

17. CHEN Y., ZHANG C., ZENG Y., LI Y. Sodium Alginate/ Ultrasonic-Assisted Biodegradation of Oestrogens in Soil. Polish Journal of Environmental Studies. 24 (4), 1535, 2015.

18. XU F.L., QIN N., ZHU Y., HE W., KONG X.Z., BARBOUR M.T., HE Q.S., WANG Y., OU-YANGA H.L., TAO S. Multimedia fate modeling of polycyclic aromatic hydrocarbons (PAHs) in Lake Small Baiyangdian, Northern China. Ecological Modelling. 252 (1), 246, 2013.

19. HUANG Y., SUN X., LIU M., ZHU J., YANG J., DU W., ZHANG, X., GAO D.Z., QADEER A., XIE, Y.S., NIE N. A multimedia fugacity model to estimate the fate and transport of polycyclic aromatic hydrocarbons (PAHs) in a largely urbanized area, Shanghai, China. Chemosphere. 217 (2019), 298, 2019.

20. HUANG L., BATTERMAN S.A. Multimedia model for polycyclic aromatic hydrocarbons (PAHs) and nitro-PAHs in Lake Michigan. Environmental Science and Technology. 48 (23), 13817, 2014.

21. LIU S., LU Y., WANG T., XIE S., JONES K.C., SWEETMAN A.J. Using gridded multimedia model to simulate spatial fate of Benzo[ $\alpha]$ pyrene on regional scale. Environment International. 63, 53, 2014.

22. ZHU Y., TAO S., SUN J., WANG X., LI X., TSANG D.C. W., ZHU, L.Z., SHEN G.F., HUANG H.J., CAI C.Y., LIU W. Multimedia modeling of the PAH concentration and distribution in the Yangtze River Delta and human health risk assessment. Science of the Total Environment. 647, 962, 2019.

23. LIU Y., ZHANG S., LI C., SHI X., ZHAO S., SUN B., ZHU, Y. A modified QWASI model for fate and transport modeling of $\mathrm{Zn}$ and $\mathrm{Pb}$ in a shallow lake during the icefree period. Science of the Total Environment. 657, 577, 2019.

24. MACKAY D., HUGHES L., POWELL D.E., KIM J. An updated Quantitative Water Air Sediment Interaction (QWASI) model for evaluating chemical fate and input parameter sensitivities in aquatic systems: Application to D5 (decamethylcyclopentasiloxane) and PCB-180 in two lakes. Chemosphere. 111, 359, 2014.

25. CHEN L.L., TSENG C.H., TSENG W.J. Development of a system dynamics model for polycyclic aromatic hydrocarbons and its application to assess the benefits of pollution reduction. Ecotoxicology and Environmental Safety. 166, 231, 2018.
26. NOUTSOPOULOS C., KOUMAKI E., SARANTOPOULOS V., MAMAIS D. Analytical and mathematical assessment of emerging pollutants fate in a river system. Journal of Hazardous Materials. 364, 48, 2019.

27. YOO Y.G., PARK J., UMH H. N., LEE S.Y., BAE S., KIM Y.H., JERNG S.E., KIM Y., YI J. Evaluating the environmental impact of the lead species in perovskite solar cells via environmental-fate modeling. Journal of Industrial and Engineering Chemistry. 70, 453, 2019.

28. MOREIRA M., AQUINO S., COUTRIM M., SILVA J., AFONSO R. Determination of endocrine-disrupting compounds in waters from Rio das Velhas, Brazil, by liquid chromatography/high resolution mass spectrometry (ESI-LC-IT-TOF/MS). Environmental Technology. 32 (12), 1409, 2011.

29. ARDITSOGLOU A. Occurrence and partitioning of endocrine-disrupting compounds in the marine environment of Thermaikos Gulf, Northern Aegean Sea, Greece. Marine pollution bulletin. 64 (11), 2443, 2012.

30. FUNAKOSHI G., KASUYA S. Influence of an estuary dam on the dynamics of bisphenol A and alkylphenols. Chemosphere, 75 (4), 491, 2009.

31. FU M., LI Z., GAO H. Distribution characteristics of nonylphenol in Jiaozhou Bay of Qingdao and its adjacent rivers. Chemosphere. 69 (7), 1009, 2007.

32. KUCH H. M., BALLSCHMITER K. Determination of endocrine-disrupting phenolic compounds and estrogens in surface and drinking water by HRGC-(NCI)-MS in the picogram per liter range. Environmental Science and Technology. 35 (15), 3201, 2001.

33. LOOS R., HANKE G., UMLAUF G., EISENREICH S.J. LC-MS-MS analysis and occurrence of octyl- and nonylphenol, their ethoxylates and their carboxylates in Belgian and Italian textile industry, waste water treatment plant effluents and surface waters. Chemosphere. 66 (4), 690, 2007.

34. FLINT S., MARKLE T., THOMPSON S., WALLACE E. Bisphenol A exposure, effects, and policy: A wildlife perspective. Journal of Environmental Management. 104, 19, 2012.

35. STAPLES C.A., WOODBURN K. B., KLECKA G.M., MIHAICH E.M., HALL A.T., ORTEGO L., CASPERS N., HENTGES S.G. Comparison of four species sensitivity distribution methods to calculate predicted no effect concentrations for bisphenol A. Human and Ecological Risk Assessment. 14 (3), 455, 2008.

36. ADAMAKIS I.D.S., MALEA P., PANTERIS E. The effects of Bisphenol A on the seagrass Cymodocea nodosa: Leaf elongation impairment and cytoskeleton disturbance. Ecotoxicology and Environmental Safety. 157, 431, 2018.

37. WRIGHT-WALTERS M., VOLZ C., TALBOTT E., DAVIS D. An updated weight of evidence approach to the aquatic hazard assessment of Bisphenol A and the derivation a new predicted no effect concentration (Pnec) using a non-parametric methodology. Science of the Total Environment. 409 (4), 676, 2011.

38. MICHAŁOWICZ J. Bisphenol A - Sources, toxicity and biotransformation. Environmental Toxicology and Pharmacology. 37 (2), 738, 2014. 